\title{
Seed Treatment with a Fungal or a Bacterial Antagonist for Reducing Corn Damping-off Caused by Species of Pythium and Fusarium
}

\author{
W. Mao, J. A. Lewis, P. K. Hebbar, and R. D. Lumsden, Biocontrol of Plant Diseases Laboratory, USDA-ARS, \\ Beltsville, MD 20705
}

\begin{abstract}
Mao, W., Lewis, J. A., Hebbar, P. K., and Lumsden, R. D. 1997. Seed treatment with a fungal or a bacterial antagonist for reducing corn damping-off caused by species of Pythium and Fusarium. Plant Dis. 81:450-454.

Bioassays were conducted under greenhouse conditions to test the efficacy of antagonists applied to corn (Zea mays) seed for protection against seed rot and seedling damping-off at 18 and $25^{\circ} \mathrm{C}$ in a field soil artificially infested with a combination of Pythium ultimum, P. arrhenomanes, and Fusarium graminearum. Biomass of Gliocladium virens isolates Gl-3 or Gl-21, Trichoderma viride isolate Tv-1, or peat-based slurry of Burkholderia cepacia isolates Bc-B, $\mathrm{Bc}-\mathrm{T}$, or $\mathrm{Bc}-1$ was coated individually onto corn seeds in one test, and $\mathrm{Gl}-3$ or Bc-B at four inoculum levels was used in another test. Seed treatments with most of the biocontrol agents, as well as with the fungicide captan, significantly $(P \leq 0.05)$ increased seedling stand, plant height and fresh weight, and decreased root rot severity compared with untreated seeds in pathogeninfested soil. Coating seeds with the biocontrol fungus $G$. virens isolate Gl-3 was the most effective treatment, resulting in greater $(P \leq 0.05)$ seedling stand, plant height, and fresh weight, and lower $(P \leq 0.05)$ severity of root rot than those parameters from seeds treated with captan or other antagonists at both temperatures. The results from the seeds treated with Gl-3 were similar to those of untreated seeds in noninfested soil. In treatments with $\mathrm{Bc}-1, \mathrm{Bc}-\mathrm{T}, \mathrm{Bc}-\mathrm{B}$, or Tv-1, incubation temperature affected plant emergence, root rot severity, plant height, and fresh weight $(P \leq 0.01)$. Conversely, in seeds coated with Gl-3 or Gl-21, these parameters were similar at both temperatures. The minimum number of propagules needed per corn seed to obtain plant emergence comparable to that from captan-treated seeds was between $10^{4}$ and $10^{5} \mathrm{CFU}$ for Gl-3 and $>10^{8}$ for Bc-B. When propagules of Gl-3 were applied at a rate $>10^{6} \mathrm{CFU}$ per seed, seedling emergence was greater $(P \leq 0.05)$ than that from captan-treated seeds.
\end{abstract}

Currently, most commercial seeds of corn hybrids sold in the United States are treated with pesticides. One of the pesticides, the fungicide captan, has been used to enhance seed germination and seedling stand by reducing the severity of seed rot and root rot caused by various soilborne pathogens, including Pythium spp. and Fusarium spp. $(1,17,25,26)$. Even with captan-treated seeds, up to $35 \%$ of corn seedlings may be affected in the midwestern areas of the United States $(5,18)$.

Biological control using antagonistic microbes alone, or as supplements to minimize the use of chemical pesticides in a system of integrated plant disease management, has become more important in recent years $(8,20)$. Beneficial microbes, including antagonistic bacteria and fungi, applied as seed treatments provide unique opportunities and benefits for crop protec-

Corresponding author: W. Mao

E-mail: wmao@asrr.arsusda.gov

Accepted for publication 24 January 1997.

Publication no. D-1997-0224-08R

This article is in the public domain and not copyrightable. It may be freely reprinted with customary crediting of the source. The American Phytopathological Society, 1997. tion, especially for protection against soilborne fungal pathogens (8). Considerable research has been done to investigate antagonistic microbes for use in seed treatments $(1,5,11,16,17)$. Many methods of large-scale production of biocontrol agents $(13,15,16,19)$ and delivery systems for applying these antagonists to seeds have been developed $(7,14,16)$. For example, Burkholderia cepacia (syn. Pseudomonas cepacia) (27) and Pseudomonas fluorescens were applied directly to pea seeds to reduce damping-off and root rot caused by Pythium spp. and Aphanomyces spp., respectively $(2,22)$. Gliocladium virens J. H. Miller, J. E. Giddens, \& A. A. Foster was coated onto cotton seeds for protection against Rhizoctonia solani (12). Pseudomonas fluorescens was applied to corn seeds by a bio-priming method for reducing Pythium damping-off (5). A peatbased inoculum of $B$. cepacia was coated onto corn seeds for suppressing soilborne diseases of corn $(10,11)$. Because these microbial strains have the ability to grow and proliferate on germinating seeds, and may eventually colonize the whole root system or rhizosphere, they are referred to as "rhizosphere competent" (8).

Despite these findings, seed treatment with antagonistic microbes, especially with fungal antagonists, to reduce damping-off of field corn has been limited. In this paper, we report the potential of seed treatments with the biocontrol fungi $G$. virens isolates Gl-3 or Gl-21, and Trichoderma viride Rifai isolate $\mathrm{Tv}-1$, and the biocontrol bacteria $B$. cepacia isolates $\mathrm{Bc}$ $\mathrm{B}, \mathrm{Bc}-\mathrm{T}$, or $\mathrm{Bc}-1$ to reduce corn seed rot and seedling damping-off caused by a combination of the pathogens Pythium ultimum Trow, Pythium arrhenomanes Drechs., and Fusarium graminearum Schwabe. Emphasis of this research was placed on (i) the effectiveness of the antagonists in reducing disease severity, (ii) the minimum number of propagules needed to coat a corn seed to have an equal or superior efficacy to the fungicide captan, and (iii) the effect of temperature on antagonists, pathogens, and corn plants.

\section{MATERIALS AND METHODS}

Microbial cultures and soil. The biocontrol fungi used in these studies were $G$. virens isolates Gl-3 and Gl-21, and $T$. viride isolate $\mathrm{Tv}-1$ from the collection of the Biocontrol of Plant Diseases Laboratory. The bacteria used were B. cepacia isolates $\mathrm{Bc}-\mathrm{B}$ (provided by Stine Seed Company, Adel, IA), Bc-T (provided by T. Heulin, Centre National de la Recherche Scientifique, Nancy, France), and Bc-1 (isolated from a soybean root in Beltsville, MD). The bacteria were grown on nutrient agar (Difco, Detroit, MI) at $24^{\circ} \mathrm{C}$ and maintained at $-80^{\circ} \mathrm{C}$ in glycerol. The pathogens $F$. graminearum and Pythium arrhenomanes were isolated from corn field soil in Beltsville, and the isolate of Pythium ultimum was provided by D. E. Mathre, Montana State University. These pathogen isolates were grown on potato dextrose agar (PDA) (Difco) at $24^{\circ} \mathrm{C}$ and maintained at $-80^{\circ} \mathrm{C}$ in glycerol. The soil used was a loamy sand, $\mathrm{pH} 6.0$ to 6.5 , collected from a corn field in Beltsville.

Preparation of inocula. The three fungal antagonists were grown on molasses yeast medium (19) in liquid fermentation for 10 days. The biomass was filtered on muslin, air-dried overnight in a transfer hood, milled to pass a $425-\mu \mathrm{m}$ screen, and stored at $4^{\circ} \mathrm{C}$. Biomass of the three antagonists consisted mostly of chlamydospores, and propagule counts were $10^{6} \mathrm{CFU} / \mathrm{g}$ as determined by a semiselective medium (21). Bacterial cultures were grown in 250$\mathrm{ml}$ Erlenmeyer flasks containing $100 \mathrm{ml}$ of sterilized tryptic soy broth (TSB) (Difco). The flasks were placed on a rotary shaker 
for $48 \mathrm{~h}$ at $23 \pm 2{ }^{\circ} \mathrm{C}$. The cultures were then formulated with Nitragin Sterile (NS) peat (LiphaTech, Milwaukee, WI) at a ratio of $1: 1(\mathrm{wt} / \mathrm{vol})$ and maintained as a slurry at $4^{\circ} \mathrm{C}$ for no more than 7 days before use. The bacterial slurry contained $10^{9}$ to $10^{10}$ $\mathrm{CFU} / \mathrm{g}$ as determined on the selective medium Pseudomonas cepacia azelaic acid tryptamine (PCAT) (3).

Pythium spp. were grown on a sterilized semisolid medium consisting of $600 \mathrm{ml}$ of Redi-Earth 3 CP (Grace-Sierra, Milpitas, $\mathrm{CA}), 330 \mathrm{ml}$ of $60 \% \mathrm{~V} 8$ juice, $10 \mathrm{~g}$ of potato dextrose broth powder (Difco), and 0.6 $\mathrm{g}$ of $\mathrm{CaCO}_{3}$ in foil-covered polypropylene flats $(12 \times 23 \times 45 \mathrm{~cm})$. The flats were autoclaved for $1 \mathrm{~h}$ on each of two successive days, inoculated with PDA plugs of the isolates, and incubated for 2 weeks at $23 \pm 2{ }^{\circ} \mathrm{C}$. The inocula contained approximately $10^{5} \mathrm{CFU} / \mathrm{g}$ as determined by the most probable number (MPN) assay (9). $F$. graminearum was cultured on a semisolid wheat bran and water $(1: 1 \mathrm{wt} / \mathrm{wt})$ medium for 10 days at $23 \pm 2{ }^{\circ} \mathrm{C}$. After incubation, the inoculum was air-dried for 3 days and milled in a blender to pass a 3.36- $\mathrm{mm}$ screen. The inoculum contained $10^{4}$ to $10^{5}$ $\mathrm{CFU} / \mathrm{g}$ as determined by serial dilution on a peptone pentachloronitrobenzene (PCNB) medium (4).

Seed treatment. In the first series of tests, $10 \mathrm{~g}$ of corn seeds (N 6330, Northrup King Corporation, Golden Valley, MN) were mixed with $4.0 \mathrm{ml}$ of an aqueous (12\%) Pelgel (LiphaTech) solution as a sticker and $2.1 \mathrm{~g}$ of a slurry of each bacterial isolate. Ten grams of seeds were mixed with $6 \mathrm{ml}$ of sticker and $1.2 \mathrm{~g}$ of biomass powder for each fungal isolate. The seeds, sticker, and biomass were mixed thoroughly; then the seeds were covered with sufficient dry NS peat to form an even, dry coating and stored at $4^{\circ} \mathrm{C}$ for no more than 5 days before planting. Seeds contained $>10^{6} \mathrm{CFU} / \mathrm{seed}$ for each fungal antagonist or $>10^{8} \mathrm{CFU} /$ seed for each bacterium.

In the second test, seeds were coated the same way except that NS peat was used to dilute Gl-3 biomass to obtain $10^{5}, 10^{4}$, or $10^{3} \mathrm{CFU} / \mathrm{seed}$. For biomass of $\mathrm{Bc}-\mathrm{B}$, a slurry of NS peat and sterile TSB medium was used to dilute the original slurry to obtain $10^{8}, 10^{7}$, or $10^{6} \mathrm{CFU} /$ seed. Seeds of N 6330 commercially pretreated with captan were provided by Northrup King.

Bioassays. Pathogen inocula were applied to soil at a rate of $3 \mathrm{~g}$ of $F$. graminearum and $5 \mathrm{~g}$ of each Pythium sp. per $150 \mathrm{~g}$ of soil. The infested soil and noninfested soil (control) were placed in 10 -cm-diameter plastic pots and immediately planted with 3 seeds per pot of treated or nontreated corn seeds. Treatments for the first series of tests are shown in Table 1 and those for the second series in Figure 1. Both tests were repeated, and the experimental design was a randomized complete block with 10 replicate pots per treatment. The first series of tests was con- ducted in greenhouse cubicles maintained at 18 or $25^{\circ} \mathrm{C}$, and the second series at $18^{\circ} \mathrm{C}$ only. Pots were watered daily for 18 days; then seedlings were harvested to determine plant stand and root rot severity. A root rot severity index was used in which $1=<2 \%$ (healthy plant), $2=3$ to $30 \%$ (slight disease), $3=31$ to $60 \%$ (moderate disease), $4=61$ to $90 \%$ (severe disease), and $5=>91 \%$ (dead plant). Plant height and fresh weight were evaluated (based on all planted seeds) only for the first series of tests. Values of $0 \mathrm{~cm}$ and $0.3 \mathrm{~g}$ were given for plant height and fresh weight, respectively, when the seeds did not germinate.

Statistical analyses. Statistical analyses were conducted using SAS Version 6.08 ed. (SAS Inc., Cary, NC) for all parameters in both tests, and for coating treatments across temperatures and the interaction between temperature and coatings in the first series of tests only. Mean separation was accomplished using Duncan's Multiple Range Test, and all tests of significance were conducted at $P \leq 0.05$. Since the results from repeated experiments were similar, data from only one experiment are presented.

\section{RESULTS}

In general, the biocontrol agents had a beneficial effect when applied to corn seeds. Only 26 and $40 \%$ of nontreated seeds germinated at the low and high temperatures, respectively, in pathogen-infested soil compared with 87 and $90 \%$, respectively, for that of untreated seeds in noninfested soil (noninfested control) (Fig.

Table 1. Effect of corn seed treatments on plant height and fresh weight of seedlings in soil infested with a combination of Pythium ultimum, P. arrhenomanes, and Fusarium graminearum at 18 and $25^{\circ} \mathrm{C}^{\mathrm{y}}$

\begin{tabular}{lcccccc}
\hline & \multicolumn{2}{c}{ Plant height $(\mathbf{c m})$} & & \multicolumn{2}{c}{ Fresh weight $(\mathbf{g})$} \\
\cline { 2 - 3 } \cline { 5 - 6 } Treatments & $\mathbf{1 8}^{\circ} \mathbf{C}$ & $\mathbf{2 5}^{\circ} \mathbf{C}$ & & $\mathbf{1 8}^{\circ} \mathbf{C}$ & $\mathbf{2 5}^{\circ} \mathbf{C}$ \\
\hline Untreated seed in pathogen-infested soil & $2.9 \mathrm{~d}^{\mathrm{z}}$ & $3.5 \mathrm{e}$ & & $1.3 \mathrm{e}$ & $1.4 \mathrm{e}$ \\
Untreated seed in noninfested soil & $12.8 \mathrm{~b}$ & $16.6 \mathrm{a}$ & & $3.7 \mathrm{~b}$ & $5.1 \mathrm{a}$ \\
Captan & $7.5 \mathrm{c}$ & $9.7 \mathrm{~cd}$ & & $2.7 \mathrm{~d}$ & $3.1 \mathrm{~cd}$ \\
Gliocladium virens isolate Gl-3 & $15.1 \mathrm{a}$ & $17.9 \mathrm{a}$ & & $4.5 \mathrm{a}$ & $5.0 \mathrm{a}$ \\
G. virens isolate Gl-21 & $11.3 \mathrm{~b}$ & $12.1 \mathrm{bc}$ & & $3.2 \mathrm{c}$ & $3.6 \mathrm{c}$ \\
Trichoderma viride isolate Tv-1 & $8.4 \mathrm{c}$ & $10.9 \mathrm{~cd}$ & & $2.7 \mathrm{c}$ & $3.5 \mathrm{c}$ \\
Burkholderia cepacia isolate Bc-B & $11.4 \mathrm{ab}$ & $15.0 \mathrm{a}$ & & $2.9 \mathrm{c}$ & $4.2 \mathrm{bc}$ \\
B. cepacia isolate Bc-T & $6.1 \mathrm{c}$ & $8.9 \mathrm{~d}$ & & $1.5 \mathrm{e}$ & $2.7 \mathrm{~d}$ \\
B. cepacia isolate Bc-1 & $5.7 \mathrm{c}$ & $11.4 \mathrm{~cd}$ & & $1.9 \mathrm{de}$ & $3.6 \mathrm{de}$ \\
\hline
\end{tabular}

${ }^{\mathrm{y}}$ Evaluations were made at harvest (18 days after planting).

${ }^{z}$ Numbers in each column followed by the same letter are not significantly different from each other according to Duncan's Multiple Range Test $(P<0.05)$.

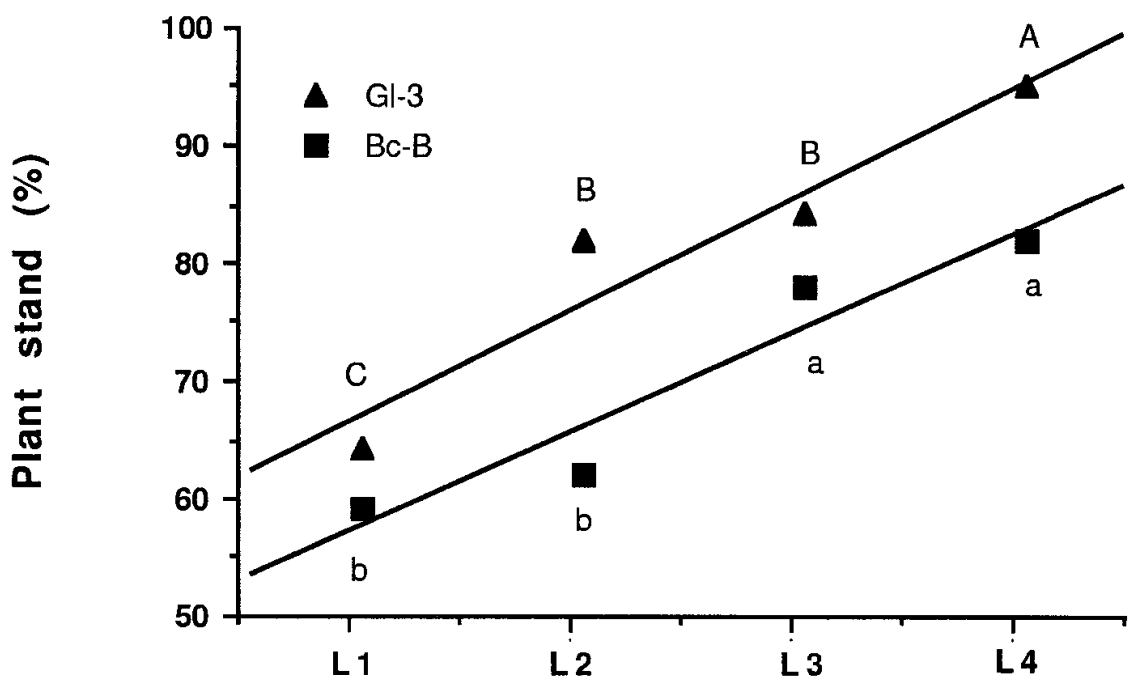

\section{Antagonist inoculum levels}

Fig. 1. Effect of inoculum level of corn seed treatment with isolates of Gliocladium virens or Burkholderia cepacia on plant stand in soil infested with a combination of Pythium ultimum, P. arrhenomanes, and Fusarium graminearum at $18^{\circ} \mathrm{C}$. Inoculum levels from L1 to L4 for Gl-3 were $10^{3}, 10^{4}$, $10^{5}$, and $10^{6}$, and for Bc-B were $10^{6}, 10^{7}, 10^{8}$, and $10^{9} . Y$ values were Gl-3 $=54.0+10.5 X, r^{2}=$ 0.967 , and $\mathrm{Bc}-\mathrm{B}=47.5+8.9 X, r^{2}=0.956$. Evaluations were made at harvest (18 days after planting). Means with the same letter are not significantly different from each other according to Duncan's Multiple Range Test $(P<0.05)$. 
2). At the low temperature, all seed treatments with antagonists, except for Bc-1, increased seedling stand from 15 to $65 \%$ $(P \leq 0.05)$ (Fig. 2). At the high temperature, all treatments increased seedling stand from 15 to $50 \%(P \leq 0.05)$. Coating seeds with Gl-3 resulted in seedling stand comparable to the noninfested control at the low temperature. Coating seeds with Gl-3 or Bc-B resulted in plant stands similar to the noninfested control at the high temperature.

All treatments containing biocontrol agents increased plant height $(P \leq 0.05)$ compared with that of untreated seeds in pathogen-infested soil (Table 1). At the low temperature, plant height from Gl-3-coated seeds was greater $(P \leq 0.05)$ than from the noninfested control, whereas treatments with Gl-21 or Bc-B resulted in plant height similar to the noninfested control. At the high temperature, treatment with Gl-3 or Bc$\mathrm{B}$ resulted in plant height comparable to that of the noninfested control. Similarly, all seed treatments except $\mathrm{Bc}-\mathrm{T}$ and $\mathrm{Bc}-1$ increased $(P \leq 0.05)$ fresh weight compared with that of untreated seeds in pathogen-infested soil (Table 1). Coating seeds with Gl-3 was the only treatment to have fresh weight similar to, or greater $(P \leq 0.05)$ than, the noninfested control at the high or low temperature, respectively.
Treatments with antagonists or captan reduced severity of root $\operatorname{rot}(P \leq 0.05)$ compared with the plants from untreated seeds in pathogen-infested soil (Fig. 3). Only the treatment with Gl-3 at both temperatures and $\mathrm{Bc}-\mathrm{B}$ at the high temperature reduced severity of root rot to values similar to those of the noninfested control. Root rot severity in treatments with other antagonists was comparable to the plants from captan-treated seeds, except with Bc1 at the low temperature and with $\mathrm{Bc}-\mathrm{T}$ at the high temperature.

In general, there were greater plant stands, plant height, fresh weight, and lower severity of root rot at the higher than at the lower temperature. However, there were significant interactions between temperature and seed treatments on plant stand $(P \leq$ $0.05)$, plant height $(P \leq 0.01)$, and fresh weight $(P \leq 0.01)$, but not on severity of root rot. Plants from untreated seeds in noninfested soil, or from seeds treated with Bc$\mathrm{B}, \mathrm{Bc}-\mathrm{T}, \mathrm{Bc}-1$, or Tv-1, had less plant height and fresh weight at the lower than at the higher temperature. In addition, plant stand was decreased from 8 to $20 \%$ in treatments with Bc-B, Bc-T, Bc-1, Tv-1, or with untreated seeds in pathogen-infested soil at the lower temperature (Fig. 2, Table 1).

In the second series of tests, the ability of the two isolates Gl-3 and Bc-B to in-

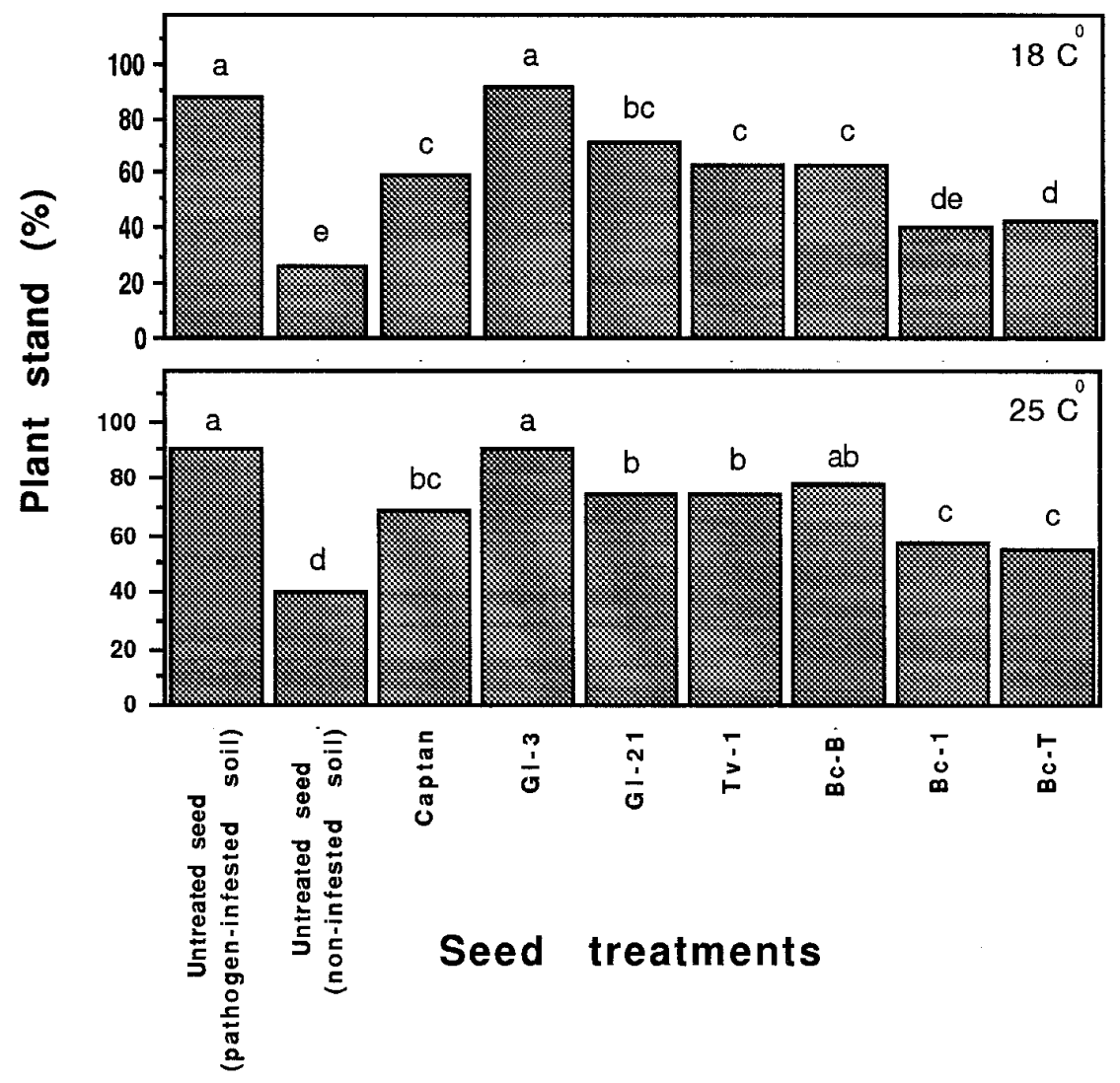

Fig. 2. Effect of corn seed treatments on plant stand in soil infested with a combination of Pythium ultimum, P. arrhenomanes, and Fusarium graminearum at 18 and $25^{\circ} \mathrm{C}$. Evaluations were made at harvest (18 days after planting). Means with the same letter are not significantly different from each other according to Duncan's Multiple Range Test $(P \leq 0.05)$. crease plant stand depended upon the amount of inoculum applied to each corn seed. There was a significant linear response for the percentage of plant stand with the amount of inoculum of both Gl-3 $\left(Y=54.0+10.5 X, r^{2}=0.967\right)$ and Bc-B $(Y$ $\left.=47.5+8.9 X, r^{2}=0.956\right)($ Fig. 1). Coating seeds with $10^{6} \mathrm{CFU}$ of Gl-3 per seed resulted in greater $(P \leq 0.01)$ plant stand than for the seeds treated with lower rates of inoculum. However, even $10^{4} \mathrm{CFU}$ of Gl-3 per seed resulted in a plant stand comparable to the noninfested control. Similarly, seed treatment with the bacterium Bc-B at rates of $10^{8}$ and $10^{9} \mathrm{CFU} /$ seed resulted in a plant stand similar to that of the noninfested control. However, stands from BcB-treated seeds were less $(P \leq 0.01)$ than those from seeds treated with the same amount of propagules of Gl-3.

\section{DISCUSSION}

The application of biocontrol agents to corn seeds led to effective control of damping-off of corn caused by a combination of Pythium spp. and $F$. graminearum under controlled environmental conditions. In this study, seed treatments with almost all of the antagonists significantly decreased severity of root rot and increased seedling stands, as well as increasing plant height and fresh weight compared with those from untreated seeds in pathogeninfested soil. Although there is little information on the biocontrol of corn diseases $(1,5,10,11,17)$, these data indicate that some fungal or bacterial antagonists have disease control potential comparable to or superior to the fungicide captan for corn. In this study, isolate G1-3 of G. virens was the most effective of the antagonists. Not only did it have the best efficacy in suppressing disease, which was significantly superior in effectiveness to that of captan and other antagonists, but also its performance was more consistent at both high and low temperatures compared with $T$. viride isolate Tv-1 and the bacterial strains. This suggests that isolate G1-3 has considerable potential for commercial application for protection against seed rot and root rot of field corn, especially under high disease pressure. In other studies, Gl-3 significantly reduced damping-off diseases of eggplant, pepper, and zinnia caused by $R$. solani and snap bean caused by Sclerotium rolfsii $(15,20)$.

Temperature has been cited as one of the most important environmental factors affecting the pathogenicity of Pythium spp. on corn, as well as the disease suppression abilities of antagonistic microbes on other crops $(5,17,24)$. In the first series of tests, the ability of $\mathrm{Tv}-1$ and three bacterial strains to reduce severity of root rot was significantly decreased when they were placed at $18^{\circ} \mathrm{C}$ compared with at $25^{\circ} \mathrm{C}$. The interaction between temperature and seed treatment suggested that the efficacy of some biocontrol agents was significantly 
influenced by temperature, indicating that some of the antagonists may be less able to compete with and effectively protect against the pathogens at lower temperature. Upadhyay et al. (24) reported that the antifungal ability of $B$. cepacia was greatly influenced by temperature. They showed that only a small amount of the antifungal compound, pyrrolnitrin, was produced at $18^{\circ} \mathrm{C}$, with maximum production at $37^{\circ} \mathrm{C}$. However, in this study, the disease suppression ability of $G$. virens isolates Gl-3 and Gl-21 were relatively consistent at both temperatures. This indicated that these isolates might have a broad temperature range for their antifungal activity. In the noninfested control treatment, plant height and fresh weight were increased by high temperature compared with low temperature, indicating that high temperatures can increase the growth rate of corn. This increased growth might enhance the host's physiological defenses against these pathogens $(5,17)$.

The methods of applying biocontrol agents to a target area are critical in the development of biocontrol strategies for protection against different diseases. Callan et al. (5) reported that colonization of corn seeds by Pythium ultimum could be extensive within $24 \mathrm{~h}$ after planting and nearly total by 48 to $72 \mathrm{~h}$, depending on soil temperature and moisture. Application of antagonists by seed treatment appears to represent the most suitable method for biocontrol in the spermosphere and rhizosphere (14). Results of this study suggest that seed treatment with an antagonistic microbe is an effective delivery system to provide a conducive environment for the biocontrol agents. In addition, a large population of an introduced antagonist in the immediate proximity of a germinating corn seed might provide a competitive advantage over resident soil microorganisms $(6,10,11)$.

In this study, to achieve activity similar to that of captan in increasing seedling stand, the minimum population needed was between $10^{4}$ and $10^{5} \mathrm{CFU} / \mathrm{seed}$ for Gl-3 and $>10^{8}$ for $\mathrm{Bc}-\mathrm{B}$. However, when the population of Gl-3 was $>10^{6} \mathrm{CFU} / \mathrm{seed}$, the effectiveness in increasing plant stand was superior to that from captan. These data suggest that an adequate population of biocontrol agent needs to be applied to corn seeds to achieve comparable seedling stands and plant growth rate to those from captan-treated seeds. In some cases, the applied biocontrol agents may fail to es-

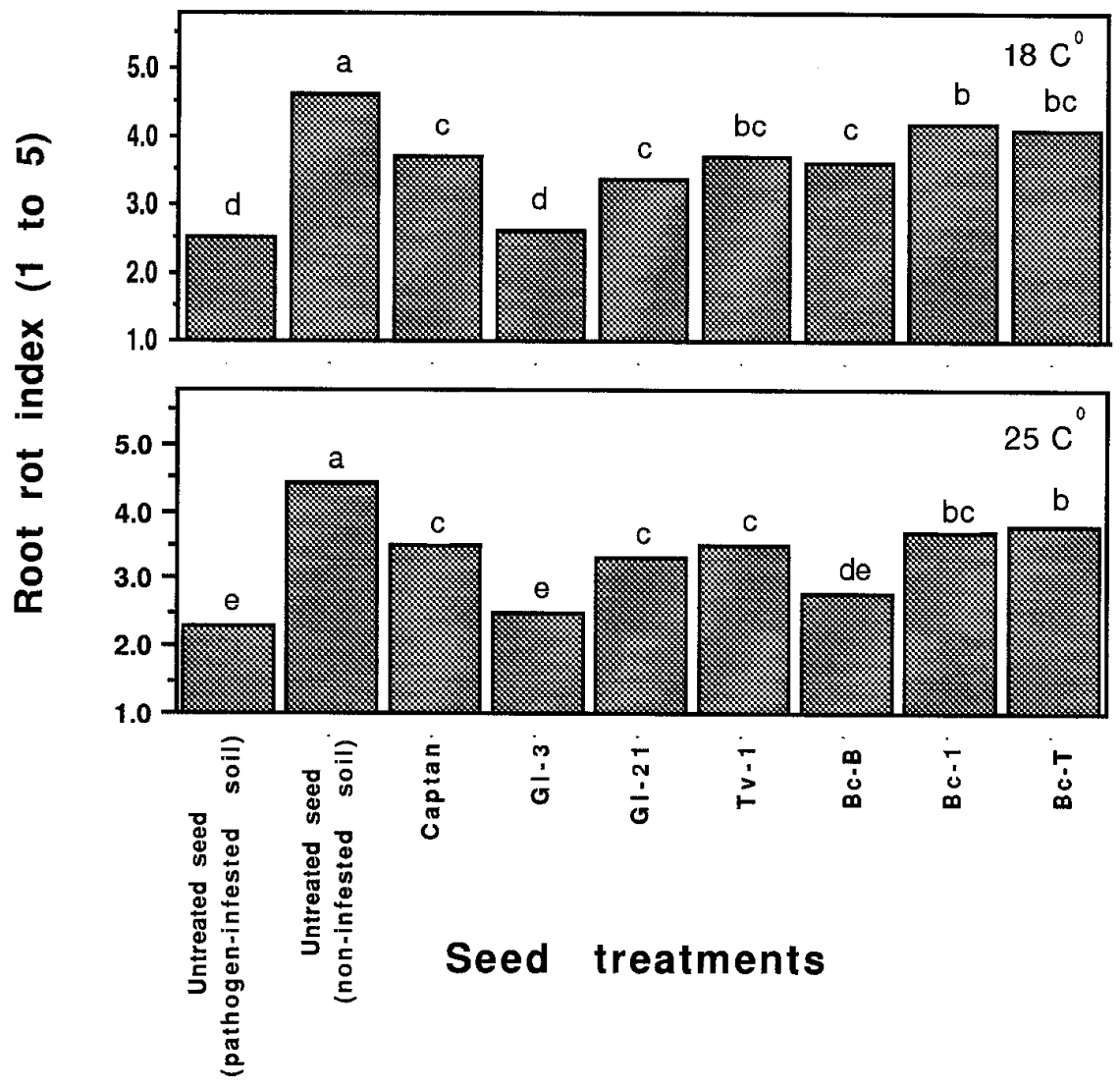

Fig. 3. Effect of corn seed treatments on severity of root rot in soil infested with a combination of Pythium ultimum, P. arrhenomanes, and Fusarium graminearum at 18 and $25^{\circ} \mathrm{C}$. Root rot severity index: $1=<2 \%$ (healthy plant), $2=3$ to $30 \%$ (slight disease), $3=31$ to $60 \%$ (moderate disease), $4=$ 61 to $90 \%$ (severe disease), and $5=>91 \%$ (dead plant). Evaluations were made at harvest (18 days after planting). Means with the same letter are not significantly different from each other according to Duncan's Multiple Range Test $(P<0.05)$. tablish on the seeds or in the rhizosphere at sufficient levels for disease suppression because of unfavorable soil temperature, $\mathrm{pH}$, or moisture (5). In order to achieve a uniform colonization of sugar beet roots, Suslow and Schroth (23) indicated that the inoculum of a rhizobacterium needed to contain at least $10^{5}$ propagules per seed. Hebbar et al. $(10,11)$ reported that at least $10^{7} \mathrm{CFU}$ of $B$. cepacia per seed were needed to suppress soilborne diseases of corn.

This study demonstrated that (i) seed treatment with sufficient propagules of a fungal or a bacterial antagonist was an effective delivery system for suppressing seed rot and root rot of corn under greenhouse conditions, (ii) temperature influenced the ability of an agent to suppress disease, and (iii) G. virens was superior to other biocontrol agents tested and has great potential to be utilized for commercial application.

\section{ACKNOWLEDGMENTS}

This work was funded by Northrup King Corporation, Golden Valley, MN. We thank H. Chow, K. Stanley, and C. McCarthy for their technical assistance.

\section{LITERATURE CITED}

1. Baird, R. E., Nankam, C., Moghaddam, P. F., and Pataky, J. 1994. Evaluation of seed treatments on Shrunken-2 sweet corn. Plant Dis. 78:817-821.

2. Bowers, J. H., and Parke, J. L. 1993. Epidemiology of Pythium damping-off and Aphanomyces root rot of peas after seed treatment with bacterial agents for biological control. Phytopathology 83:1466-1473.

3. Burbage, D. A., Sasser, M., and Lumsden, R. D. 1982. A medium selective for Pseudomonas cepacia. (Abstr.) Phytopathology $72: 706$.

4. Burgess, L. W., and Liddell, C. M. 1983. Manual for Fusarium Research. pp:5. University of Sydney, Sydney, Australia.

5. Callan, N. W., Mathre, D. E., and Miller, J. B. 1990. Bio-priming seed treatment for biological control of Pythium ultimum preemergence damping-off in sh2 sweet corn. Plant Dis. 74:368-372.

6. Chao, W. L., Nelson, E. B., Harman, G. E., and Hoch, H. C. 1986. Colonization of the rhizosphere by biological control agents applied to seeds. Phytopathology 76:60-65.

7. Fravel, D. R., Connick, W. J., Jr., and Lewis, J. A. 1996. Formulation of microorganisms to control plant diseases. In: Formulation of Microbial Biopesticides, Beneficial Microorganisms and Nematodes. H. D. Burges, ed. Chapman and Hall, London. In press.

8. Harman, G. E. 1991. Seed treatments for biological control of plant disease. Crop Prot. 10:166-171.

9. Harris, R. F., and Sommers, L. E. 1968. Platedilution frequency technique for assay of microbial ecology. Appl. Microbiol. 16:330-334.

10. Hebbar, P. K., Atkinson, D., Tucker, W., and Dart, P. J. 1992. Suppression of Fusarium moniliforme by maize root-associated Pseudomonas cepacia. Soil Biol. Biochem. 24:1009-1220.

11. Hebbar, P. K., Davey, A. G., Merrin, J., McLoughlin, T. J., and Dart, P. J. 1992. Pseudomonas cepacia, a potential suppressor of maize soil-borne diseases-seed inoculation and maize root colonization. Soil Biol. Biochem. 24:999-1007. 
12. Howell, C. R., and Stipanovic, R. D. 1995. Mechanisms in the biocontrol of Rhizoctonia solani-induced cotton seedling disease by Gliocladium virens: Antibiosis. Phytopathology 85:469-472.

13. Jackson, M. A., and Schisler, D. A. 1995. Liquid culture production of microsclerotia of Colletotrichum truncatum for use as bioherbicidal propagules. Mycol. Res. 99:879-884.

14. Lewis, J. A. 1991. Formulation and delivery systems of biocontrol agents with emphasis on fungi. Pages 279-287 in: The Rhizosphere and Plant Growth. D. L. Keister and P. B. Cregan, eds. Kluwer Academic Publishers, Dordrecht, Netherlands.

15. Lewis, J. A., Fravel, D. R., Lumsden, R. D., and Shasha, B. S. 1995. Application of biocontrol fungi in granular formulations of pregelatinized starch-flour to control dampingoff diseases caused by Rhizoctonia solani. Biol. Control 5:397-404

16. Lumsden, R. D., Lewis, J. A., and Fravel, D. R. 1995. Formulation and delivery of biocontrol agents for use against soilborne plant pathogen. Pages 166-182 in: Biorational Pest Control Agents Formulation and Delivery. F. R. Hall and J. W. Barry, eds. American Chemical Society, Washington, DC.
17. Mathre, D. E., and Johnston, R. H. 1995. Combined biological and chemical seed treatments for control of two seedling diseases of Sh2 sweet corn. Plant Dis. 79:11451148 .

18. McGee, D. C. 1988. Maize Diseases-A Reference Source for Seed Technologists. Part 3: Diseases that are not seedborne or seed transmitted. American Phytopathological Society, St. Paul, MN. pp. 100-103.

19. Papavizas, G. C., Dunn, M. T., Lewis, J. A., and Beagle-Ristaino, J. 1984. Liquid fermentation technology for experimental production of biocontrol fungi. Phytopathology 74:11711175.

20. Papavizas, G. C., and Lewis, J. A. 1989. Effect of Gliocladium and Trichoderma on damping-off and blight of snapbean caused by Sclerotium rolfsii in the greenhouse. Plant Pathol. 38:277-286.

21. Papavizas, G. C., and Lumsden, R. D. 1982. Improved medium for isolation of Trichoderma spp. from soil. Plant Dis. 66:10191020.

22. Parke, J. L., Rand, R. E., Joy, A. E., and King, E. B. 1991. Biological control of Pythium damping-off and Aphanomyces root rot of peas by application of Pseudomonas cepacia or P. fluorescens to seed. Plant Dis. 75:987992.

23. Suslow, T. V., and Schroth, M. N. 1982. Rhizobacteria of sugar beets: Effects of seed application and root colonization on yield Phytopathology 72:199-206.

24. Upadhyay, R. S., Visintin, L., and Jayaswal, R. K. 1991. Environmental factors affecting the antagonism of Pseudomonas cepacia against Trichoderma viride. Can. J. Microbiol. 37:880-884

25. Wilson, D. O., Jr., and Mohan, S. K. 1992 Effect of seed moisturization and fungicide treatment on final stand of low vigor Shrunken 2 sweet corn inbreds. J. Prod. Agric. 5:510-512.

26. Wilson, D. O., Jr., Mohan, S. K., Knott, E. A. and Shafii, B. 1993. Evaluation of fungicide seed treatments for Shrunken-2 "Supersweet" sweet corn. Plant Dis. 77:348-351.

27. Yabuchi, E., Kosako, Y., Oyaizu, H., Yano, H., Hasimoto, Y., Ezaki, T., and Arakawa, M. 1992. Proposal of Burkholderia gen. nov. and transfer of seven species of the Pseudomonas homology Group II to a new genus, with type species Burkholderia cepacia (Palleroni and Holmes, 1981) comb. nov. Microbiol. Immunol. 34:1251-1275.

\section{ERRATUM / Volume 81, Number 5, 1997}

In the article "Seed treatment with a fungal or a bacterial antagonist for reducing corn damping-off caused by species of Pythium and Fusarium" by W. Mao, J. A. Lewis, P. K. Hebbar, and R. D. Lumsden on pages 450 to 454, in Figures 2 and 3, the label for the first bar should read "Untreated seed (noninfested soil)" and for the second bar should read "Untreated seed (pathogen-infested soil)." 